\title{
Synthesis, structural elucidation, characterization and theoretical DFT study of 1-(o-tolyl)biguanidium chloride
}

\section{Kamel Kaabi, Kacem Klai, Emmanuel Wenger, Christian Jelsch, Frédéric Lefebvre and Cherif Ben Nasr}

Acta Cryst. (2020). C76, 572-578

\section{\# IUCr Journals CRYSTALLOGRAPHY JOURNALS ONLINE \\ Copyright (C) International Union of Crystallography \\ Author(s) of this article may load this reprint on their own web site or institutional repository provided that this cover page is retained. Republication of this article or its storage in electronic databases other than as specified above is not permitted without prior permission in writing from the IUCr. \\ For further information see https://journals.iucr.org/services/authorrights.html}




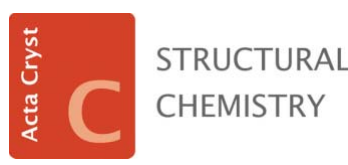

ISSN 2053-2296

Received 28 February 2020

Accepted 11 May 2020

Edited by M. Kubicki, Adam Mickiewicz University, Poland

Keywords: hydrogen bonding; IR spectroscopy crystal structure; Hirshfeld surface; contact enrichment ratio; electrostatic potential; biguanidium.

CCDC reference: 1877569

Supporting information: this article has supporting information at journals.iucr.org/C

\section{Synthesis, structural elucidation, characterization and theoretical DFT study of 1-(o-tolyl)biguanidium chloride}

\author{
Kamel Kaabi, ${ }^{a}$ Kacem Klai, ${ }^{a}$ Emmanuel Wenger, ${ }^{\mathrm{b}}$ Christian Jelsch, ${ }^{\mathrm{b}}$ Frédéric \\ Lefebvre $^{\mathrm{c}}$ and Cherif Ben Nasr ${ }^{\mathrm{a} *}$
}

aLaboratoire de Chimie des Matériaux, Université de Carthage, Faculé des Sciences de Bizerte, 7021 Zarzouna, Tunisia ${ }^{\mathbf{b}}$ Université de Lorraine, CNRS, CRM2, F-54000 Nancy, France, and ' 'Laboratoire de Chimie Organométallique de Surface (LCOMS), Ecole Supérieure de Chimie Physique Electronique, 69626 Villeurbanne Cedex, France. *Correspondence e-mail: cherif_bennasr@yahoo.fr

The structure of the new salt 1-(o-tolyl)biguanidium chloride, $\mathrm{C}_{9} \mathrm{H}_{14} \mathrm{~N}_{5}{ }^{+} \cdot \mathrm{Cl}^{-}$, has been determined by single-crystal X-ray diffraction. The salt crystallizes in the monoclinic space group $C 2 / c$. In this structure, the chloride and biguanidium hydrophilic ions are mostly connected to each other via $\mathrm{N}-\mathrm{H} \cdots \mathrm{N}$ and $\mathrm{N}-$ $\mathrm{H}$. . Cl hydrogen bonds to form layers parallel to the $a b$ plane around $y=\frac{1}{3}$ and $y=\frac{2}{3}$. The 2-methylbenzyl groups form layers between these layers around $y=0$ and $y=\frac{1}{2}$, with the methyl group forming $\mathrm{C}-\mathrm{H} \cdots \pi$ interactions with the aromatic ring. Intermolecular interactions on the Hirshfeld surface were investigated in terms of contact enrichment and electrostatic energy, and confirm the role of strong hydrogen bonds along with hydrophobic interactions. A correlation between electrostatic energy and contact enrichment is found only for the strongly attractive $\left(\mathrm{N}-\mathrm{H} \cdots \mathrm{Cl}^{-}\right)$and repulsive contacts. Electrostatic energies between ions reveal that the interacting biguanidium cation pairs are repulsive and that the crystal is maintained by attractive cation $\cdots \mathrm{Cl}^{-}$dimers. The vibrational absorption bands were identified by IR spectroscopy.

\section{Introduction}

Organic salts have received a lot of attention in recent years due to their noncovalent interactions, such as hydrogen bonding, that play significant roles in various fields ranging from molecular recognition, host-guest chemistry, crystal engineering, supramolecular chemistry, biochemistry and pharmaceutical chemistry to materials science (Metrangolo et al., 2005; Steiner, 2002; Desiraju \& Steiner, 2002; Mu et al., 2008; Babu \& Nangia, 2011; Félix-Sonda et al., 2014). Guanidine and its derivatives have been widely used in the manufacture of plastics, resins, rubber chemicals, rocket propellants and disinfectants. They also have biotechnological applications in the field of protein separation (Pignataro, 2012). The Galega officinalis plant containing guanidine was used as a treatment for sugar diabetes in medieval Europe (Bailey \& Campbell, 2007). Biguanides, such as metformin ( $N, N$-dimethylbiguanide), were synthesized from guanidines in the 1920 s and showed antidiabetic properties. Biguanides often refer to a class of drugs that act as oral antihyperglycemic agents (Rang et al., 2003); moreover, they are used as analgesic and antimalarial (Pignard, 1962) drugs. Among the derivatives of guanidine, $o$-tolylbiguanide (TBG) is a nontoxic compound and can be used in solution for topical application (Robert \& Stogniew, 2012) and as a viscosity-lowering agent of protein solutions in liquid pharmaceutical formulations (Larson et al., 
2018). TBG has atoms able to generate strong hydrogen bonding, which plays a very important role in interactions with biomolecules (Hubberstey \& Suksangpanya, 2004). In this article, we report the first crystal structure of 1-(o-tolyl)biguanidium chloride, (I) (see Scheme 1), its Hirshfeld surface analysis and a physicochemical characterization. The crystal packing is an organic salt network constructed by hydrogen bonds. The contact enrichments were computed by Hirshfeld surface analysis in order to evaluate which contacts play major roles in the stabilization of the crystal packing.<smiles>[CH2]/[NH+]=C(\N=C(/NC)Nc1ccccc1C)NCl</smiles>

(I)

Scheme 1

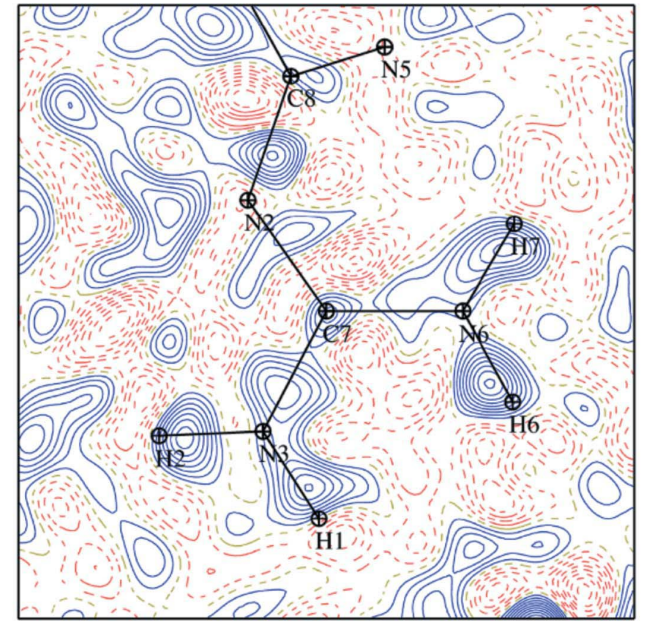

(a)

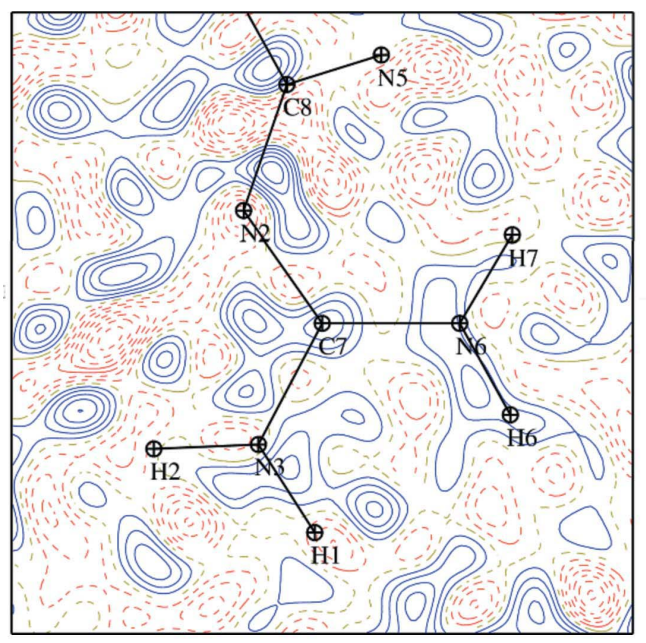

(b)

Figure 1

Fourier residual electron density $(a)$ after spherical atom refinement and (b) after refinement using the transferred multipolar atom model. The contour level is $0.05 \mathrm{e}^{-3}$. The colour key is: blue positive, red negative and yellow zero.

Table 1

Experimental details.

Crystal data

Chemical formula

$M_{\mathrm{r}}$

Crystal system, space group

Temperature $(\mathrm{K})$

$a, b, c(\AA)$

$\beta\left({ }^{\circ}\right)$

$V\left(\AA^{3}\right)$

$Z$

Radiation type

$\mu\left(\mathrm{mm}^{-1}\right)$

Crystal size (mm)

Data collection

Diffractometer

Absorption correction

$T_{\min }, T_{\max }$

No. of measured, independent and observed $[I>2 \sigma(I)]$ reflections

$R_{\text {int }}$

$(\sin \theta / \lambda)_{\max }\left(\AA^{-1}\right)$

Refinement

$R\left[F^{2}>2 \sigma\left(F^{2}\right)\right], w R\left(F^{2}\right), S$

No. of reflections

No. of parameters

No. of restraints

$\mathrm{H}$-atom treatment

$\Delta \rho_{\max }, \Delta \rho_{\min }\left(\mathrm{e} \AA^{-3}\right)$

Computer programs: CrysAlis PRO (Rigaku OD, 2015), SHELXT (Sheldrick, 2015a), SHELXL (Sheldrick, 2008, 2015b), MoPro (Jelsch et al., 2005) and DIAMOND (Brandenburg, 1998).

\section{Experimental}

\subsection{Synthesis and crystallization}

An aqueous solution of $37 \% \mathrm{HCl}(40 \mathrm{mg}, 0.4 \mathrm{mmol}$, SigmaAldrich) was added dropwise to a solution of 1-(o-tolyl)biguanide (41 mg, $0.4 \mathrm{mmol}$, Sigma-Aldrich) in ethanol (10 ml). After stirring for $45 \mathrm{~min}$, the resultant solution was left to evaporate at room temperature. Crystals of the title salt, (I), which remained stable under normal conditions of temperature and humidity, were isolated after several days and subjected to X-ray diffraction analysis (yield 73\%). Analysis calculated (\%): C 47.43, H 6.15, N 30.74; found: C 45.93, H 5.82, N 28.15 .

\subsection{Refinement}

Crystal data, data collection and structure refinement details are summarized in Table $1 . \mathrm{H}$ atoms were located by successive differential Fourier syntheses.

The structure was refined with the full-matrix least-squares procedure using the SHELXL program (Sheldrick, 2015b). The structure was then refined with the MoPro software (Jelsch et al., 2005) using the multipolar atom model (Hansen \& Coppens, 1978). The $X-\mathrm{H}$ bond lengths were elongated according to standard neutron diffraction distances (Allen \& Bruno, 2010). The molecular electron density was transferred from the ELMAM database of multipolar atoms (Domagała et 
al., 2012). The $\mathrm{TBG}^{+} \cdot \mathrm{Cl}^{-}$salt was set to be electrically neutral, with each ion carrying a unitary formal charge.

When using the multipolar atom model instead of the spherical one, the r.m.s. Fourier residual electron density was

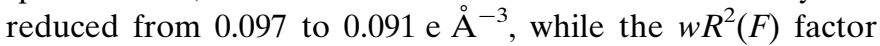
diminished from 4.5 to $3.4 \%$ (Fig. 1 ).

\subsection{Electrostatic energy calculations}

The electrostatic energy $E_{\text {elec }}$ was computed with the VMoPro module of MoPro software (Jelsch et al., 2005) using the refined structure with transferred multipolar atom model. The intermolecular electrostatic interaction energies were evaluated with the exact potential and multipole methods (EP/ MM) first described by Volkov et al. (2004).

The $E_{\text {elec }}$ value for a contact type was obtained by direct summation over atomic contacts between the reference and all the surrounding molecules. To take into account only the shortest contacts which contribute to the Hirshfeld surface contacts atom/atom decomposition, a cutoff of the sum of the van der Waals radii plus $0.3 \AA$ was applied to the interatomic distance. The average $E_{\text {elec }}$ value was obtained by dividing the summation by the number of contacts.

The dimer electrostatic interaction energies were obtained by a double summation over atoms $a_{i}$ and $b_{j}$ constituting the two moieties $\left[E_{\mathrm{dimer}}=\Sigma a_{i} \Sigma b_{j} E_{\mathrm{elec}}\left(a_{i}, b_{j}\right)\right]$.

\subsection{Theoretical calculations}

Theoretical calculations were made with the GAUSSIAN09 software (Frisch et al., 2010) and the B3LYP DFT method. In a first series of calculations, the different cations resulting from the protonation of TBG were investigated using the B3LYP/6$31 \mathrm{G}(\mathrm{d}, \mathrm{p})$ method in order to determine what was the more stable species. In all cases, the IR spectrum was calculated and

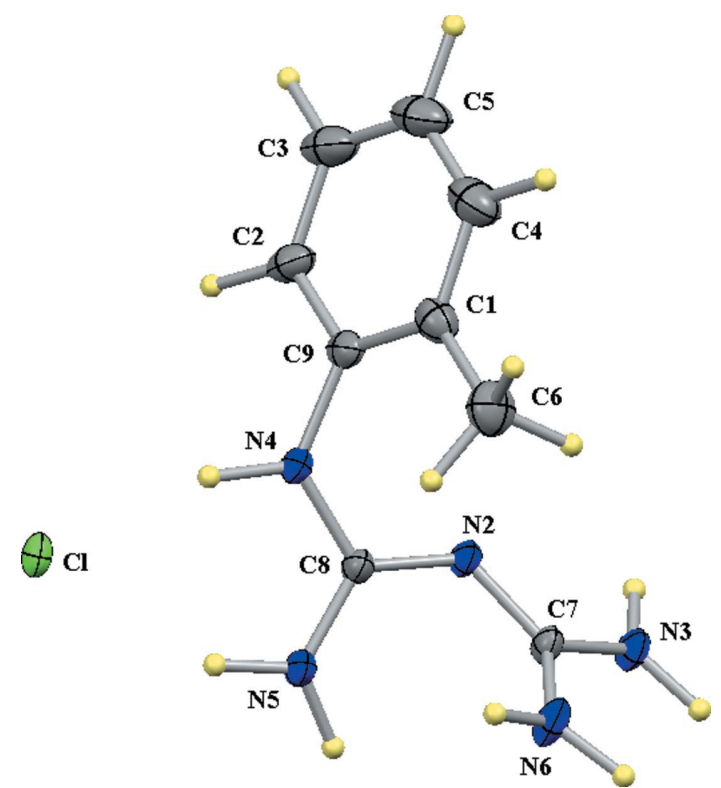

Figure 2

The molecular structure of the title salt, (I), with displacement ellipsoids drawn at the $40 \%$ probability level.
Table 2

Hydrogen-bond geometry $\left(\AA{ }^{\circ}\right)$.

\begin{tabular}{lllll}
\hline$D-\mathrm{H} \cdots A$ & $D-\mathrm{H}$ & $\mathrm{H} \cdots A$ & $D \cdots A$ & $D-\mathrm{H} \cdots A$ \\
\hline $\mathrm{N} 4-\mathrm{H} 4 \cdots \mathrm{Cl}$ & $1.01(8)$ & $2.17(7)$ & $3.1584(9)$ & $163(1)$ \\
$\mathrm{N} 5-\mathrm{H} 5 \cdots \mathrm{Cl}$ & $1.01(9)$ & $2.37(9)$ & $3.2880(9)$ & $150(6)$ \\
$\mathrm{N} 6-\mathrm{H} 7 \cdots \mathrm{N} 5$ & $1.02(15)$ & $2.52(6)$ & $2.9156(13)$ & $103(5)$ \\
$\mathrm{C} 6-\mathrm{H} 10 \cdots \mathrm{C} 8$ & $1.08(12)$ & $2.65(9)$ & $3.1420(15)$ & $108(5)$ \\
$\mathrm{N} 3-\mathrm{H} 1 \cdots \mathrm{Cl}$ & $1.01(9)$ & $2.44(6)$ & $3.3431(9)$ & $148(4)$ \\
$\mathrm{N} 6-\mathrm{H} 6 \cdots \mathrm{Cl}^{\mathrm{i}}$ & $1.02(9)$ & $2.28(9)$ & $3.2398(9)$ & $157(1)$ \\
$\mathrm{N} 5-\mathrm{H} 3 \cdots \mathrm{Cl}^{\mathrm{ii}}$ & $1.01(10)$ & $2.32(13)$ & $3.2454(9)$ & $150(3)$ \\
$\mathrm{N} 6-\mathrm{H} 7 \cdots \mathrm{Cl}^{\mathrm{iii}}$ & $1.02(15)$ & $2.34(18)$ & $3.2284(9)$ & $146(11)$ \\
$\mathrm{N} 3-\mathrm{H} 2 \cdots \mathrm{N} 2{ }^{\mathrm{iv}}$ & $1.01(16)$ & $1.96(15)$ & $2.9754(12)$ & $174(1)$ \\
\hline Symmetry codes: (i) $x, y, z+1 ;$ & (ii) $x,-y+2, z+\frac{1}{2} ;$ (iii) $-x+1, y,-z+\frac{1}{2} ;$ (iv) \\
$-x+\frac{1}{2},-y+\frac{3}{2},-z+1$. &
\end{tabular}

the absence of imaginary frequencies was checked in order to verify that the structure corresponded to a true minimum.

A second series of calculations was performed on the most stable structure, which corresponded to that found by X-ray diffraction using the B3LYP/6-311++G(p,d) method in order to obtain results which could be compared to those obtained previously on neutral TBG. Both a full optimization of all atoms and an optimization of only the H-atom positions, the other atoms being at crystallographic positions, were made and in both cases the electronic properties, such as the energies and the shapes of the highest occupied molecular orbital (HOMO) and the lowest unoccupied molecular orbital (LUMO), were calculated.

\subsection{IR spectroscopy}

The IR spectra were recorded in the range $4000-400 \mathrm{~cm}^{-1}$ with a PerkinElmer FT-IR 1000 spectrophotometer using samples dispersed in spectroscopically pure $\mathrm{KBr}$ pressed into a pellet.

\subsection{Hirshfeld surface analysis}

Fingerprint plots of the contacts in (I) were generated with the CrystalExplorer3.1 software (Spackman \& Jayatilaka, 2009). The analysis of contact types and their enrichment were computed with the MoProViewer program (Guillot et al., 2014). In order to obtain, in one step, the integral Hirshfeld surfaces around the $\mathrm{TBG}^{+}$cation and the $\mathrm{Cl}^{-}$anion, they were computed around an ensemble of two moieties which are not in contact with each other in the crystal. As the Hc atoms bound to carbon are hydrophobic and the Hn atoms bound to nitrogen are more polar, the two atom types have different interaction propensities and were treated separately.

\section{Results and discussion}

\subsection{X-ray diffraction study}

The main geometrical features of the different chemical entities of the new salt, $\mathrm{C}_{9} \mathrm{H}_{14} \mathrm{~N}_{5}{ }^{+} \cdot \mathrm{Cl}^{-},(\mathbf{I})$, are reported in Tables 1 and 2. X-ray crystal structure analysis reveals that the complex crystallizes in the monoclinic space group $C 2 / c$.

The asymmetric unit of $\mathbf{I}$, shown in Fig. 2, consists of a $\mathrm{Cl}^{-}$ anion and a 1-(o-tolyl)biguanidium $\left(\mathrm{TGB}^{+}\right)$organic cation. 
This cation does not result only from the protonation of TBG on one of its $\mathrm{N}$ atoms, but also from the migration of one proton from one $\mathrm{N}$ atom to another. This structure has also been observed previously during the protonation of biguanidium chloride (Serb et al., 2014; Niranjana et al., 2017). The reaction mechanism of its formation is believed to proceed via a tautomeric equilibrium leading to the more stable tautomer form.

Fig. 3 is a representation of the hydrogen bonds around the $\mathrm{TBG}^{+}$cation and shows the hydrogen bonds generated essentially by the amino $\mathrm{NH}_{2}$ groups which act as donors and the $\mathrm{Cl}^{-}$ions which act as acceptors.

The various components of salt (I) are linked to each via $\mathrm{N}-\mathrm{H} \cdots \mathrm{Cl}$ and $\mathrm{N}-\mathrm{H} \cdots \mathrm{N}$ hydrogen bonds (Table 2), and they are arranged so as to form cavities along the $c$ direction at $x=\frac{1}{2}$ and $y=\frac{1}{2}$ (Figs. S1 and S2 in the supporting information). Within the organic cation, an examination of the $\mathrm{C}-\mathrm{N}$ bond lengths of the aliphatic group gives a mean value of $1.338 \AA$ (Table S1 in the supporting information). They are short for $\mathrm{C}-\mathrm{N}$ single bonds, but still not quite as contracted as one would expect for a fully established $\mathrm{C}=\mathrm{N}$ double bond. All these bond-length features are consistent with an imino resonance form (Yang et al., 1995; Grobelny et al., 1995) and suggest a great contribution from it to the stability of (I).

The values of the $\mathrm{C}-\mathrm{N}$ bond lengths in $(\mathbf{I})$ are close to those of metformin chloride (Şerb et al., 2014; Niranjana et al., 2017) (Table 3). Fig. 4 shows that the $\mathrm{C}-\mathrm{N}$ distances are clustered in two groups. The first group of hybridized bonds has a mean $\mathrm{C}-\mathrm{N}$ distance of $1.339 \AA$ in $\mathrm{TBG}^{+}$and $1.337 \AA$ in metformin. The dispersion of values is much larger in $\mathrm{TBG}^{+}$, with a sample standard deviation (ssd) of $0.008 \AA$ compared to a value of $0.003 \AA$ in metformin. The second group concerns $\mathrm{N} 4-\mathrm{C}$ bonds and has much less agreement between the two molecules as $\mathrm{N}-\mathrm{C}_{\text {tolyl }}=1.418(2) \AA$ in $\mathrm{TBG}^{+}$and $\mathrm{N}-\mathrm{C}_{\text {methyl }}=$

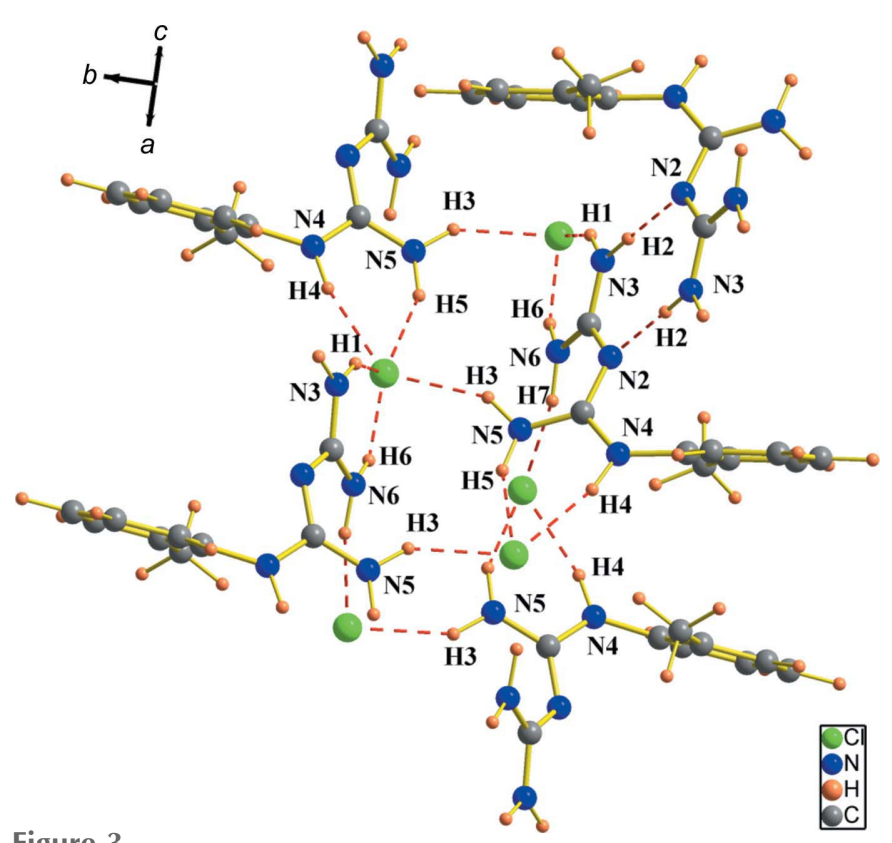

Figure 3

Representation of the hydrogen bonds around the $\mathrm{TBG}^{+}$cation in $(\mathbf{I})$.
Table 3

Comparison between $\mathrm{C}-\mathrm{N}$ bond distances in 1-(o-tolyl)biguanidium chloride, (I), and metformin chloride (Niranjana et al., 2017).

\begin{tabular}{llll}
\hline II & & Metformin chloride & \\
\hline $\mathrm{N} 6-\mathrm{C} 7$ & $1.3334(13)$ & $\mathrm{N} 5-\mathrm{C} 4$ & $1.3398(3)$ \\
$\mathrm{N} 3-\mathrm{C} 7$ & $1.3335(13)$ & $\mathrm{N} 4-\mathrm{C} 4$ & $1.3407(4)$ \\
$\mathrm{N} 2-\mathrm{C} 7$ & $1.3407(13)$ & $\mathrm{N} 3-\mathrm{C} 4$ & $1.3332(3)$ \\
$\mathrm{N} 2-\mathrm{C} 8$ & $1.3307(13)$ & $\mathrm{C} 4-\mathrm{N} 3$ & $1.3332(3)$ \\
$\mathrm{N} 5-\mathrm{C} 8$ & $1.3385(13)$ & $\mathrm{N} 2-\mathrm{C} 3$ & $1.3372(4)$ \\
$\mathrm{N} 4-\mathrm{C} 8$ & $1.3516(14)$ & $\mathrm{N} 1-\mathrm{C} 3$ & $1.3376(4)$ \\
$\mathrm{N} 4-\mathrm{C} 9$ & $1.4180(14)$ & $\mathrm{N} 1-\mathrm{C} 1\left(\mathrm{CH}_{3}\right)$ & $1.4590(4)$ \\
& & $\mathrm{N} 1-\mathrm{C} 2\left(\mathrm{CH}_{3}\right)$ & $1.4566(5)$ \\
\hline
\end{tabular}

1.4566 (3)/1.4590 (3) $\AA$ in metformin; this is explained by the different chemical natures of the substituents on the $\mathrm{N} 4$ atom.

In the crystal lattices of both salts, the molecules are arranged by 'pairs' of molecules symmetrically related by a centre of inversion.

\subsection{Contacts analysis}

A Hirshfeld surface analysis was undertaken to further characterize the nature of the intermolecular contacts (Table 4). The spikes in the fingerprint plots at short contact distances correspond to $\mathrm{N} \cdots \mathrm{H}$ and $\mathrm{Cl} \cdots \mathrm{H}$ hydrogen bonds (Fig. 5). The enrichment ratio (Jelsch et al., 2014, 2015) is a powerful tool to deduce which type of contacts are over- or under-represented in the crystal packing. The contact enrichment $E_{X Y}$ between chemical species $X$ and $Y$ is the ratio between the actual contacts $C_{X Y}$ in the crystal and the $R_{X Y}$ 'random' contacts, computed as if all types of contacts had the same probability to form. $R_{X Y}$ values are obtained from probability products $R_{X Y}=S_{X} \cdot S_{Y}$, where $S_{X}$ is the proportion of $X$ on the Hirshfeld surface. The $\mathrm{Cl} \cdots \mathrm{Hn}$ strong hydrogen

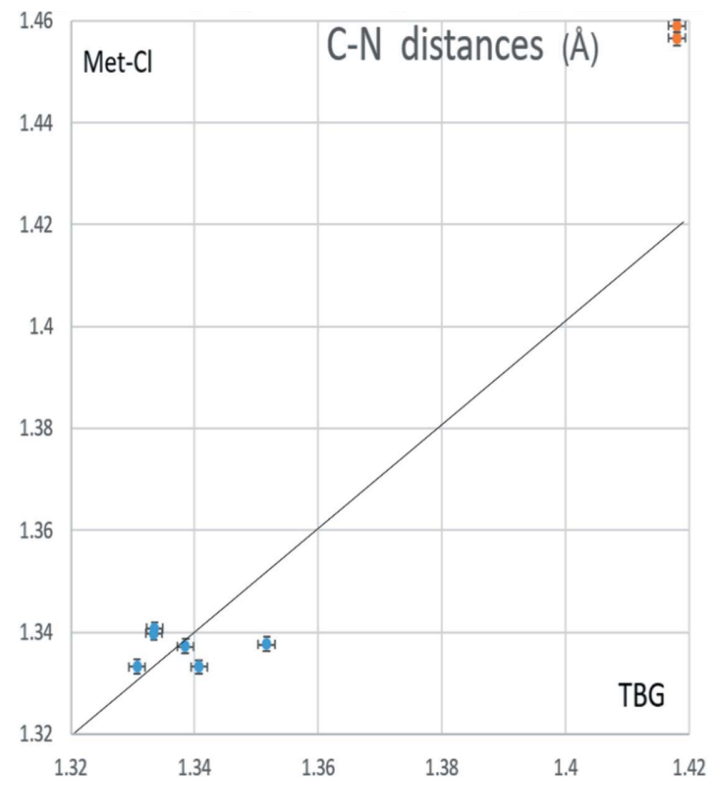

Figure 4

Scatterplot of the $\mathrm{C}-\mathrm{N}$ distances in $\mathrm{TBG}^{+}$and metformin chloride (Niranjana et al., 2017). 
Table 4

Analysis of contacts on the Hirshfeld surface.

Reciprocal contacts $X \cdots Y$ and $Y \cdots X$ are merged. The second line shows the chemical content on the surface. The \% of contact types between chemical species are given in the next five lines, followed by their enrichment ratios. The major contacts, as well as the most enriched ones, are highlighted in bold. The lower part of the table gives the contact enrichment when the $\mathrm{N}$ atom with lone pair Nlp is distinguished from the other nitrogen $\mathrm{Nh}$ atoms $\left(\mathrm{NH}\right.$ and $\mathrm{NH}_{2}$ groups).

\begin{tabular}{lcccccc}
\hline Atom & $\mathrm{Hn}$ & $\mathrm{C}$ & $\mathrm{N}$ & $\mathrm{Cl}$ & $\mathrm{Hc}$ & \\
\hline Surface $\%$ & 27.3 & 19.3 & 8.1 & 15.5 & 29.8 & \\
Hn & 4.4 & & & & & \\
C & 6.4 & 5.0 & & \% contacts & & \\
N & 4.9 & 1.1 & 0 & & & \\
Cl & $\mathbf{2 7 . 3}$ & 1.2 & 1.2 & 0.2 & $\mathbf{1 1 . 0}$ & \\
Hc & 7.8 & $\mathbf{1 8 . 7}$ & 7.1 & 3.8 & & \\
Hn & 0.58 & & & & & \\
C & 0.62 & $\mathbf{1 . 4 3}$ & & Enrichment & & \\
N & $\mathbf{1 . 2 4}$ & $\mathbf{0 . 4 2}$ & 0 & & & \\
Cl & $\mathbf{2 . 9 2}$ & 0.19 & 0.48 & 0.08 & & \\
Hc & 0.48 & $\mathbf{1 . 6 9}$ & $\mathbf{1 . 6 8}$ & 0.38 & $\mathbf{1 . 2 5}$ & \\
\hline & & & & & & \\
Atom & Hn & C & Nlp & Nh & Cl & Hc \\
\hline Nlp & $\mathbf{2 . 3 7}$ & 0.05 & 0 & 0 & 0 & 0.98 \\
Nh & 0.39 & 0.36 & 0 & 0 & 0.88 & $\mathbf{2 . 2 4}$ \\
\hline
\end{tabular}

bonds are the most abundant and the most enriched contact types. The hydrophobic $\mathrm{Hc}$ atoms form mostly $\mathrm{C}-\mathrm{H} \cdots \pi$ interactions with the $\mathrm{C}$ and $\mathrm{N} s p^{2}$ atoms of the tolyl and biguanide moieties. The nonpolar contacts Hc..Hc, C ‥C and $\mathrm{Hc} \cdot \mathrm{C}$ are all over-represented due to the presence of hydrophobic layers in the crystal packing.

In order to analyze correlations with enrichment ratios, the electrostatic energy $E_{\text {elec}}$, derived from the transferred multipolar atom model, was computed for the different
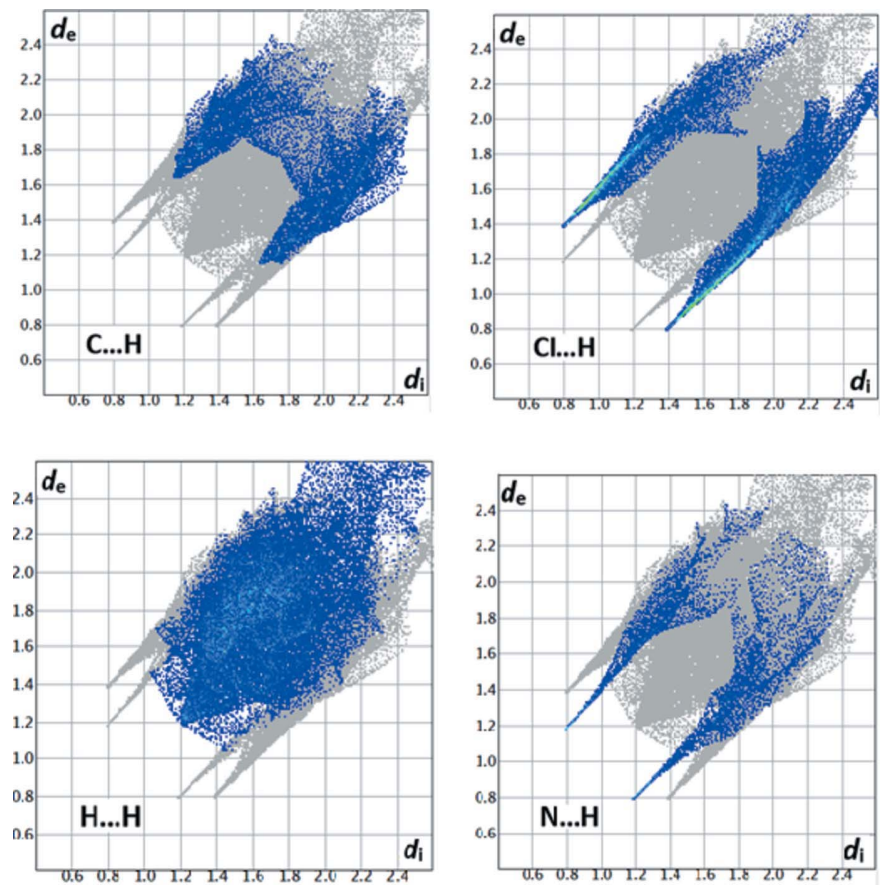

Figure 5

Fingerprint plots of the contacts at the Hirshfeld surface. The scales on the axes are from 0.6 to 2.4 .
Table 5

Electrostatic energy $\left(\mathrm{kJ} \mathrm{mol}^{-1}\right)$ between the $\mathrm{TBG}^{+}$cations and the neighbouring cations in direct contact.

The summation was performed by attributing a coefficient $\frac{1}{2}$ to the involutional symmetry operators $\sigma$ and a unitary weight to the others.

\begin{tabular}{llll}
\hline & Symmetry code & Energy & Coefficient \\
\hline $\mathrm{TBG}^{+} \ldots \mathrm{Cl}^{-}$ & $x, y, z$ & -385 & $\frac{1}{2}$ \\
& $x, y, z+1$ & -410 & 1 \\
& $x,-y+2, z+\frac{1}{2}$ & -369 & 1 \\
$\mathrm{TBG}^{+} . \mathrm{TBG}^{+}$ & $-x+1, y,-z+\frac{1}{2}$ & -369 & $\frac{1}{2}$ \\
& $x,-y+1, z-\frac{1}{2}$ & 126 & 1 \\
& $-x+1, y,-z+\frac{1}{2}$ & 216 & $\frac{1}{2}$ \\
& $-x+1, y,-z+\frac{3}{2}$ & 245 & $\frac{1}{2}$ \\
& $-x+1,-y+1,-z+1$ & 135 & $\frac{1}{2}$ \\
& $-x+\frac{1}{2}, y-\frac{1}{2},-z+\frac{1}{2}$ & 138 & 1 \\
Sum & $-x+\frac{1}{2},-y+\frac{3}{2},-z$ & 141 & $\frac{1}{2}$ \\
& $-x+\frac{1}{2},-y+\frac{3}{2},-z+1$ & 60 & $\frac{1}{2}$ \\
\hline
\end{tabular}

contact types. The $E_{\text {elec }}$ values were averaged for all $X \cdots Y$ contacts where the $d_{X Y}$ distance is shorter than the sum of the van der Waals radii plus $0.3 \AA$. The scatterplot of $E_{\text {elec }}$ and enrichment ratios is shown in Fig. 6.

The $\mathrm{Cl} \cdots \mathrm{Hn}$ strong hydrogen bond is by far the most energetic contact type (average of $-172 \mathrm{~kJ} \mathrm{~mol}^{-1}$ ), followed by $\mathrm{N} \cdot \mathrm{Hn}$ (average of $-33 \mathrm{~kJ} \mathrm{~mol}^{-1}$ for three contacts). If only the $\mathrm{N} 3-\mathrm{H} 2 \cdots \mathrm{N} 2{ }^{\mathrm{iv}}$ strong hydrogen bond involving the $\mathrm{N}$ atom with an electron lone pair is considered (N6$\mathrm{H} 7 \cdots \mathrm{N} 5$ excluded), the $\mathrm{N} \cdot \cdots \mathrm{Hn}$ energy reaches $-58 \mathrm{~kJ} \mathrm{~mol}^{-1}$ and the enrichment is 2.37 . On the other side of the scatterplot, the $\mathrm{Cl}^{-} \ldots \mathrm{Cl}^{-}$interaction is very unfavourable energetically and is strongly under-represented.

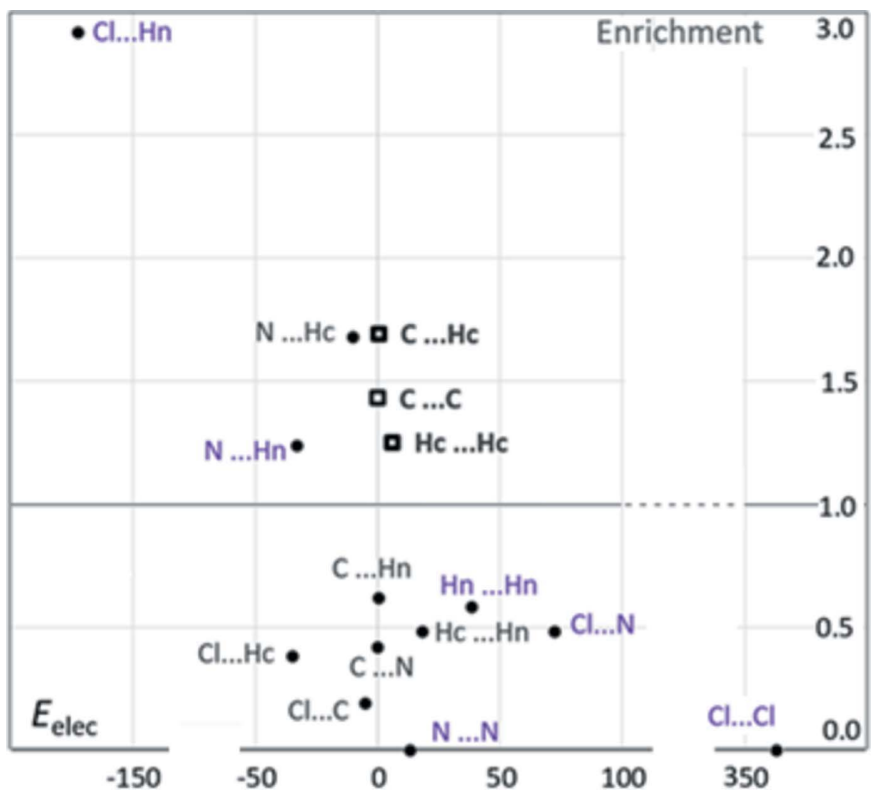

Figure 6

Scatterplot of the average electrostatic energy $E_{\text {elec }}\left(\mathrm{kJ} \mathrm{mol}^{-1}\right)$ and the enrichment ratio for the different contact types. For $\mathrm{Cl} \cdots \mathrm{C}, \mathrm{N} \cdots \mathrm{N}$ and $\mathrm{Cl} \cdots \mathrm{Cl}$, as there was no contact shorter than the sum of the van der Waals radii plus $0.3 \AA$, the energy was computed for two 'spherical' atoms at this distance. Hydrophobic contacts are in bold, while contacts between charged atoms are in purple. 
Table 6

Calculated energies of the possible cations obtained by protonation of 1-(o-tolyl)biguanide.

\begin{tabular}{lll}
\hline Structure & Absolute energy $(\mathrm{Ha})$ & $\begin{array}{l}\text { Relative energy versus } \\
\text { structure } \mathbf{6}\left(\mathrm{kJ} \mathrm{mol}^{-1}\right)\end{array}$ \\
\hline $\mathbf{1}$ & -624.898406392 & 230 \\
$\mathbf{2}$ & -624.903083434 & 216 \\
$\mathbf{3}$ & -624.916688817 & 182 \\
$\mathbf{4}$ & -624.95458411 & 83 \\
$\mathbf{5}$ & -624.966125315 & 52 \\
$\mathbf{6}$ & -624.986333171 & 0 \\
$\mathbf{7}$ & -624.964705612 & 55 \\
\hline
\end{tabular}

Besides the strong hydrogen bonds, the only enriched contacts are the three hydrophobic interactions $(\mathrm{Hc} \cdots \mathrm{Hc}$, C. . C and C..Hc) and the N..Hc contacts. The $E_{\text {elec }}$ electrostatic energies of these four enriched interactions are however very small (Fig. 6). If one omits the most attractive $\left(\mathrm{Cl}^{-} \cdots \mathrm{Hn}\right.$ and $\left.\mathrm{N} \cdot \mathrm{Hn}\right)$ and most repulsive $\left(\mathrm{Cl}^{-} \cdots \mathrm{Cl}^{-}\right)$ interactions, the weaker contacts show globally no clear correlation between enrichment and $E_{\text {elec }}$ values (Fig. 6).

The biguanidium cation interacts directly with four $\mathrm{Cl}^{-}$ anions and the electrostatic energies computed between the two moieties are similar and in the range from -369 to $-410 \mathrm{~kJ} \mathrm{~mol}^{-1}$ (Table 5). On the other hand, there are seven independent $\mathrm{TBG}^{+} \ldots \mathrm{TBG}^{+}$dimers in the crystal packing. The $E_{\text {elec }}$ interaction energies between interacting $\mathrm{TBG}^{+}$cations are in the range from 60 to $245 \mathrm{~kJ} \mathrm{~mol}^{-1}$, which indicates that all these dimers are repulsive from an electrostatic point of view. In the energy sum over all contacts, the involutional symmetry operators were counted with a half weight, as noninvolutional symmetries $\sigma$ represent two reciprocal contacts $\left(\sigma\right.$ and $\sigma^{1}$ ). The summation leads to an attractive $E_{\text {elec }}$ energy of $-472 \mathrm{~kJ} \mathrm{~mol}^{-1}$ between a $\mathrm{TBG}^{+}$cation and its nearest neighbours.

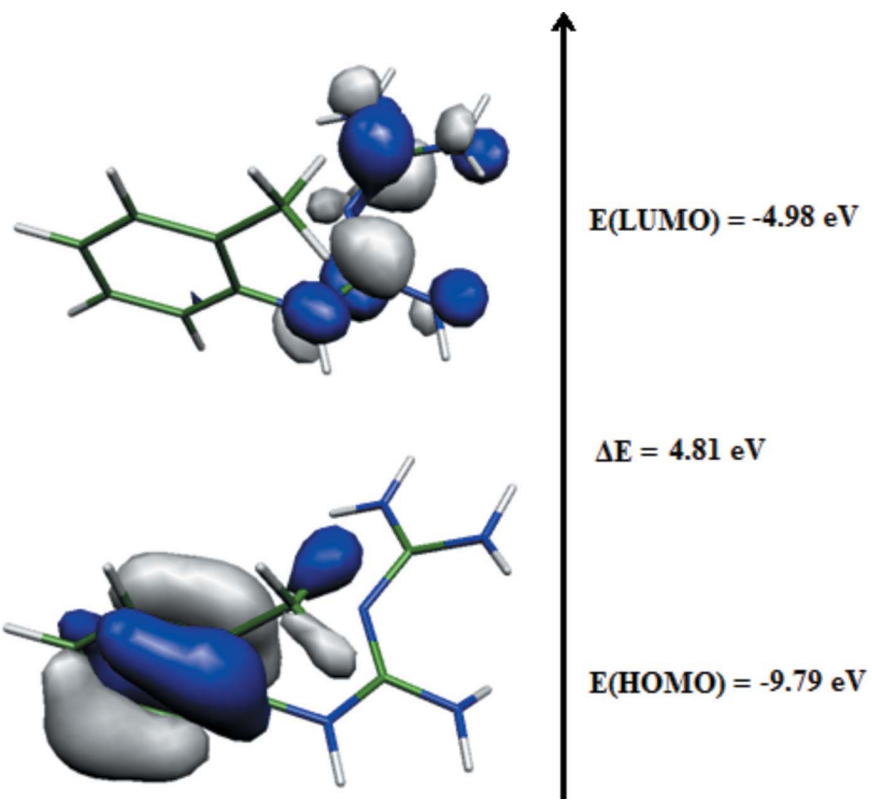

Figure 7

Frontier orbitals in (I) calculated at the B3LYP/6-311++G(d,p) level.

\subsection{Theoretical study}

As the molecule can potentially have seven forms, corresponding to different protonation of the $\mathrm{N}$ atoms (Scheme 2), theoretical studies were carried out with the GAUSSIAN09 software (Frisch et al., 2010) using the B3LYP/6-31+G* method. The structures were fully optimized and the absence of imaginary frequencies was checked, determining if they correspond to real minima.<smiles>Cc1ccccc1N/C(=N/N)N/C([NH+])=N\[Hg]</smiles>

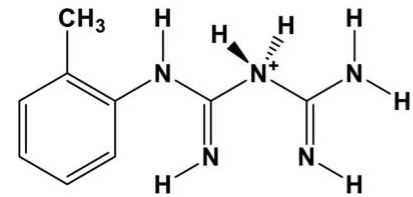

Structure 2<smiles>Cc1ccccc1[NH2+]/C(=N\N)NN</smiles>

Structure 3<smiles>Cc1ccccc1N/C(=N/O)[NH+]=C(N)N/C=C/[Mg]</smiles><smiles>[H]/[W]=C(N)/N=C(\N)Nc1ccccc1C</smiles><smiles>Cc1ccccc1/N=C(\N)N/C(N)=[NH+]\[Hg]</smiles>

Scheme 2

The energy values are listed in Table 6. As observed experimentally, the most stable structure is $\mathbf{6}$, where the proton has moved on one $\mathrm{N}-\mathrm{H}$ group and where the two $\mathrm{C}=\mathrm{N}$ double bonds are conjugated. Structure 5, where the two $\mathrm{C}=\mathrm{N}$ bonds are also conjugated, and structure 7 have the same energy, which is $c a 50 \mathrm{~kJ} \mathrm{~mol}^{-1}$ greater than that of structure 6. Structure 4 has an energy which is $c a 80 \mathrm{~kJ} \mathrm{~mol}^{-1}$ greater. Finally, the structures resulting from the protonation of the amine groups are far less stable (with an energy at least $180 \mathrm{~kJ} \mathrm{~mol}^{-1}$ greater than that of structure 6).

A more detailed analysis was then performed on structure 6 using the B3LYP/6-311++G(d,p) method. Fig. 7 shows the HOMOs and LUMOs for (I) after full optimization. Clearly, the HOMOs are localized primarily on the aromatic ring, while the LUMOs are located on the $\mathrm{N}$ atoms. The HOMO and LUMO energies are -9.79 and $-4.98 \mathrm{eV}$, respectively. The value of the energy separation between the HOMO and LUMO orbitals, called the energy band gap, is $4.81 \mathrm{eV}$. This large HOMO-LUMO energy gap implies a high kinetic stability and a low chemical reactivity of the molecular system. 


\subsection{Molecular electrostatic potential (MEP) analysis}

The MEP of (I) was computed at the B3LYP/6-31++G(d,p) level and is shown in Fig. 8. The MEP is used to predict the molecular reactive behaviour towards electrophilic and nucleophilic attack and defined sites of the electrophile and nucleophile. The electrostatic potential maps are colour coded and are subdivided into many regions where those various colours are used to identify different potentials. Intermediate potentials are assigned colours according to the following colour spectrum: red $<$ orange $<$ yellow $<$ green $<$ blue. As seen from Fig. 8, the positive region is localized on the $\mathrm{N}$ atoms, while the negative region is located inside the aromatic ring.

\section{Conclusion}

In summary, a novel 1-(o-tolyl)biguanidium chloride salt has been successfully synthesized at room temperature by slow evaporation. The enrichment ratio, derived from the Hirshfeld contact surface analysis, allows the determination of which types of contacts are over or under-represented. The crystal packing is stabilized by intermolecular $\mathrm{N}-\mathrm{H} \cdots \mathrm{Cl}$ and $\mathrm{N}-$ $\mathrm{H} \cdots \mathrm{N}$ strong hydrogen bonds, as well as $\mathrm{C}-\mathrm{H} \cdots \pi$ and $\mathrm{N}-$ $\mathrm{H} \cdots \mathrm{N}$ interactions, which are all quite over-represented. The $\mathrm{N} s p^{2}$ atoms form most likely $\mathrm{C}-\mathrm{H} \cdots \mathrm{N}$ interactions on the two sides of the $s p^{2}$ plane. There is an anticorrelation between contact enrichment and electrostatic energy only for the strongest attractions and the most repulsive interaction. According to the enrichment values, it can be inferred that the $\mathrm{Cl}^{-} \cdot \ldots \mathrm{Hn}$ and $\mathrm{N} \cdot \mathrm{Hn}$ strong hydrogen bonds, the avoidance of $\mathrm{Cl}^{-} \cdot \mathrm{Cl}^{-}$contacts and the three hydrophobic interaction types are the driving forces in the stabilization of the $\mathrm{TBG}^{+} /$ $\mathrm{Cl}^{-}$crystal packing. $E_{\text {elec }}$ values between interacting dimers (Table 5) show that all cation dimers are repulsive, which is more than compensated for by the attractive cation-anion dimers which maintain the crystal cohesion. Moreover, the HOMO-LUMO energy gap suggests a good stability of this compound.

\section{Acknowledgements}

The Secretary of State for Scientific Research and Technology of Tunisia is acknowledged for a visiting grant to KK. We thank the $\mathrm{PMD}^{2} \mathrm{X}$ X-ray diffraction facility of the Institute Jean Barriol, University of Lorraine, for X-ray diffraction measurements, data processing and analysis, and providing reports for publication: (http://crm2.univ-lorraine.fr/lab/fr/ services/pmd2x).

\section{References}

Allen, F. H. \& Bruno, I. J. (2010). Acta Cryst. B66, 380-386.

Babu, N. J. \& Nangia, A. (2011). Cryst. Growth Des. 11, 2662-2679.

Bailey, C. \& Campbell, I. (2007). Metformin: the gold standard. A scientific handbook, p. 288. Chichester, UK: Wiley.

Brandenburg, K. (1998). DIAMOND. Crystal Impact GbR, Bonn, Germany.

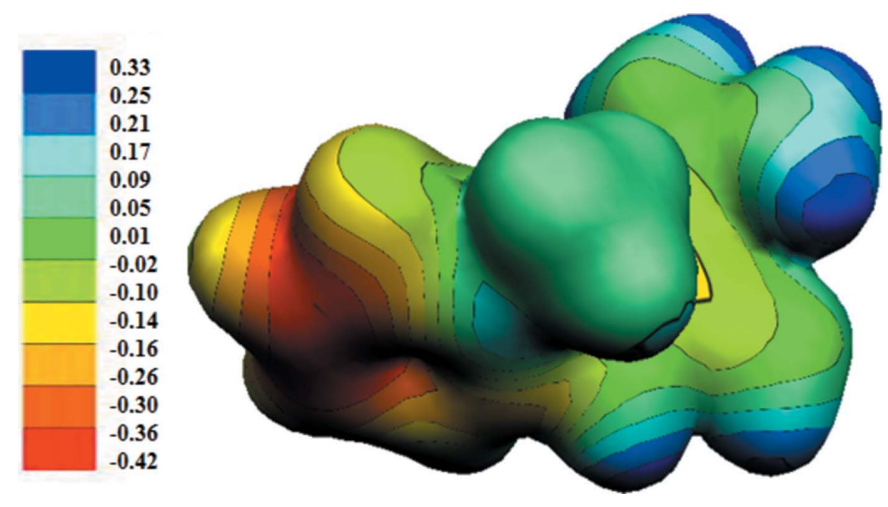

Figure 8

MEP surface of (I) calculated at the B3LYP/6-311++G(d,p) level.

Desiraju, G. R. \& Steiner, T. (2002). In The Weak Hydrogen Bond in Structural Chemistry and Biolog. Oxford University Press.

Domagała, S., Fournier, B., Liebschner, D., Guillot, B. \& Jelsch, C. (2012). Acta Cryst. A68, 337-351.

Félix-Sonda, B. C., Rivera-Islas, J., Herrera-Ruiz, D., Morales-Rojas, H. \& Höpfl, H. (2014). Cryst. Growth Des. 14, 1086-1102.

Frisch, M. J., et al. (2010). GAUSSIAN09. Revision D.01. Gaussian Inc., Wallingford, CT, USA. https://gaussian.com/.

Grobelny, R., Glowiak, T., Mrozinski, J., Baran, W. \& Tomasik, P. (1995). Pol. J. Chem. 69, 559-565.

Guillot, B., Enrique, E., Huder, L. \& Jelsch, C. (2014). Acta Cryst. A70, C279.

Hansen, N. K. \& Coppens, P. (1978). Acta Cryst. A34, 909-921.

Hubberstey, P. \& Suksangpanya, U. (2004). Struct. Bond. 111, $33-$ 83.

Jelsch, C., Ejsmont, K. \& Huder, L. (2014). IUCrJ, 1, 119-128.

Jelsch, C., Guillot, B., Lagoutte, A. \& Lecomte, C. (2005). J. Appl. Cryst. 38, 38-54.

Jelsch, C., Soudani, S. \& Ben Nasr, C. (2015). IUCrJ, 2, 327-340.

Larson, A. M., Love, K., Weight, A. K., Crane, A., Langer, R. S. \& Klibanov, A. M. (2018). US Patent No. 9925263.

Metrangolo, P., Neukirch, H., Pilati, T. \& Resnati, G. (2005). Acc. Chem. Res. 38, 386-395.

Mu, Z., Shu, L., Fuchs, H., Mayor, M. \& Chi, L. (2008). J. Am. Chem. Soc. 130, 10840-10841.

Niranjana Devi, R., Jelsch, C., Israel, S., Aubert, E., Anzline, C. \& Hosamani, A. A. (2017). Acta Cryst. B73, 10-22.

Pignard, P. (1962). Ann. Biol. Clin. 20, 325-333.

Pignataro, B. (2012). Editor. In New Strategies in Chemical Synthesis and Catalysis. Chichester, UK: Wiley.

Rang, H. P., Dale, M. M., Ritter, J. M. \& Moore, P. K. (2003). Editors. In Pharmacology. Edinburgh: Churchill Livingstone.

Rigaku OD (2015). CrysAlis PRO. Rigaku Oxford Diffraction Ltd, Yarnton, Oxfordshire, England.

Robert, A. \& Stogniew, M. (2012). US Patent Appl. No. 13/546149.

Şerb, M. D., Kalf, I. \& Englert, U. (2014). CrystEngComm, 16, 1063110639.

Sheldrick, G. M. (2008). Acta Cryst. A64, 112-122.

Sheldrick, G. M. (2015a). Acta Cryst. A71, 3-8.

Sheldrick, G. M. (2015b). Acta Cryst. C71, 3-8.

Spackman, M. A. \& Jayatilaka, D. (2009). CrystEngComm, 11, 1932.

Steiner, T. (2002). Angew. Chem. Int. Ed. 41, 48-76.

Volkov, A., Koritsanszky, T. \& Coppens, P. (2004). Chem. Phys. Lett. 391, 170-175.

Yang, R. N., Wang, D. M., Hou, Y. M., Xue, B. Y., Jin, D. M., Chen, L. R. \& Luo, B. S. (1995). Acta Chem. Scand. 49, 771-773. 


\section{supporting information}

Acta Cryst. (2020). C76, 572-578 [https://doi.org/10.1107/S2053229620006336]

Synthesis, structural elucidation, characterization and theoretical DFT study of 1-(o-tolyl)biguanidium chloride

\section{Kamel Kaabi, Kacem Klai, Emmanuel Wenger, Christian Jelsch, Frédéric Lefebvre and Cherif Ben Nasr}

Computing details

Data collection: CrysAlis PRO (Rigaku OD, 2015); cell refinement: CrysAlis PRO (Rigaku OD, 2015); data reduction: CrysAlis PRO (Rigaku OD, 2015); program(s) used to solve structure: SHELXT (Sheldrick, 2015a); program(s) used to refine structure: SHELXL (Sheldrick, 2008, 2015b) and MoPro (Jelsch et al., 2005); molecular graphics: DIAMOND (Brandenburg, 1998).

2-[Amino(iminiumyl)methyl]-1-(2-methylphenyl)guanidine chloride

Crystal data

$\mathrm{C}_{9} \mathrm{H}_{14} \mathrm{~N}_{5}^{+} \cdot \mathrm{Cl}^{-}$

$M_{r}=227.68$

Monoclinic, $C 2 / c$

Hall symbol: $-\mathrm{C} 2 \mathrm{yc}$

$a=18.4640(7) \AA$

$b=13.7652(6) \AA$

$c=9.3158(3) \AA$

$\beta=98.847(4)^{\circ}$

$V=2339.54(16) \AA^{3}$

$Z=8$

\section{Data collection}

Agilent SuperNova Dual Source diffractometer with an Atlas detector

Radiation source: fine-focus sealed tube Mirror monochromator

$\omega$ scans

Absorption correction: multi-scan (CrysAlis PRO; Rigaku OD, 2015)

$T_{\min }=0.850, T_{\max }=1.000$

Refinement

Refinement on $F^{2}$

Least-squares matrix: full

$R\left[F^{2}>2 \sigma\left(F^{2}\right)\right]=0.057$

$w R\left(F^{2}\right)=0.065$

$S=0.97$

3970 reflections

192 parameters

47 restraints
$F(000)=960$

$D_{\mathrm{x}}=1.293 \mathrm{Mg} \mathrm{m}^{-3}$

Mo $K \alpha$ radiation, $\lambda=0.71073 \AA$

Cell parameters from 8409 reflections

$\theta=3.7-32.4^{\circ}$

$\mu=0.30 \mathrm{~mm}^{-1}$

$T=110 \mathrm{~K}$

Prism, white

$0.23 \times 0.15 \times 0.04 \mathrm{~mm}$

29979 measured reflections

3970 independent reflections

2840 reflections with $>2.0 \sigma(I)$

$R_{\text {int }}=0.063$

$\theta_{\max }=31.9^{\circ}, \theta_{\min }=3.7^{\circ}$

$h=-27 \rightarrow 27$

$k=-19 \rightarrow 20$

$l=-13 \rightarrow 13$

Primary atom site location: structure-invariant direct methods

Secondary atom site location: difference Fourier map

Hydrogen site location: difference Fourier map

All $\mathrm{H}$-atom parameters refined

$w=1 /\left[2.1 * \sigma^{2}\left(F_{\mathrm{o}}{ }^{2}\right)\right]$

$(\Delta / \sigma)_{\max }=-0.002$ 


$$
\Delta \rho_{\max }=0.64 \mathrm{e} \AA^{-3} \quad \Delta \rho_{\min }=-0.40 \mathrm{e} \AA^{-3}
$$

\section{Special details}

Refinement. Refinement of $\mathrm{F}^{2}$ against reflections. The threshold expression of $\mathrm{F}^{2}>2 \operatorname{sigma}\left(\mathrm{F}^{2}\right)$ is used for calculating Rfactors(gt) and is not relevant to the choice of reflections for refinement. R-factors based on $\mathrm{F}^{2}$ are statistically about twice as large as those based on F, and R-factors based on ALL data will be even larger.

A single crystal was carefully selected under a polarizing microscope in order to perform its structural analysis. X-ray diffraction data were collected on a SuperNova (Dual, $\mathrm{Cu}$ at zero Atlas) diffractometer at $110 \mathrm{~K}$, using graphitemonochromated Mo K $\alpha=0.71073 \AA$ radiation. The structure was solved using a direct method with the SHELXT program The structure was refined using the full-matrix least-squares procedure using the SHELXL program (Sheldrick, 2008; Sheldrick 2015). The drawings were made with Diamond (Brandenburg, 1998). Crystal data and experimental parameters used for the intensity data collection are summarized in Table 1.

Fractional atomic coordinates and isotropic or equivalent isotropic displacement parameters $\left(\AA^{2}\right)$

\begin{tabular}{|c|c|c|c|c|}
\hline & $x$ & $y$ & $z$ & $U_{\text {iso }} * / U_{\text {eq }}$ \\
\hline $\mathrm{Cl}$ & $0.414821(13)$ & $0.88578(2)$ & -0.04433 & $0.01974(2)$ \\
\hline $\mathrm{N} 2$ & $0.33610(4)$ & $0.78604(6)$ & $0.42786(10)$ & $0.01757(7)$ \\
\hline N3 & $0.30580(4)$ & $0.81756(7)$ & $0.65219(9)$ & $0.01997(8)$ \\
\hline H1 & $0.3193(6)$ & $0.8406(9)$ & $0.756(10)$ & $0.0244(2)^{*}$ \\
\hline $\mathrm{H} 2$ & $0.257(10)$ & $0.7853(8)$ & $0.6192(12)$ & $0.0244(2)^{*}$ \\
\hline N4 & $0.36565(5)$ & $0.75392(7)$ & $0.20089(10)$ & $0.01987(8)$ \\
\hline $\mathrm{H} 4$ & $0.3785(6)$ & $0.7843(8)$ & $0.109(10)$ & $0.0244(2)^{*}$ \\
\hline N5 & $0.39543(5)$ & $0.90299(7)$ & $0.29973(9)$ & $0.02277(8)$ \\
\hline $\mathrm{H} 3$ & $0.3896(7)$ & $0.957(10)$ & $0.3710(9)$ & $0.0280(3)^{*}$ \\
\hline H5 & $0.4122(6)$ & $0.9204(8)$ & $0.204(10)$ & $0.0279(3)^{*}$ \\
\hline N6 & $0.41948(5)$ & $0.86368(8)$ & $0.61097(9)$ & $0.02504(8)$ \\
\hline H6 & $0.4310(6)$ & $0.8816(9)$ & $0.718(10)$ & $0.0302(3)^{*}$ \\
\hline $\mathrm{H} 7$ & $0.460(10)$ & $0.8615(10)$ & $0.5498(9)$ & $0.0302(3)^{*}$ \\
\hline $\mathrm{C} 7$ & $0.35465(5)$ & $0.82389(8)$ & $0.56102(12)$ & $0.01720(8)$ \\
\hline $\mathrm{C} 8$ & $0.36674(5)$ & $0.81496(8)$ & $0.31484(12)$ & $0.01704(8)$ \\
\hline C9 & $0.35099(6)$ & $0.65283(8)$ & $0.20189(13)$ & $0.02048(9)$ \\
\hline $\mathrm{C} 1$ & $0.39317(6)$ & $0.59042(9)$ & $0.29875(14)$ & $0.02626(11)$ \\
\hline $\mathrm{C} 2$ & $0.29635(6)$ & $0.61761(8)$ & 0.09368 (13) & $0.02776(11)$ \\
\hline $\mathrm{H} 8$ & $0.2707(5)$ & $0.667(10)$ & $0.0104(8)$ & $0.0335(3)^{*}$ \\
\hline $\mathrm{C} 3$ & $0.28159(7)$ & $0.51917(10)$ & $0.08305(15)$ & $0.03686(13)$ \\
\hline H9 & $0.240(10)$ & $0.4912(5)$ & $-0.0010(9)$ & $0.0449(4)^{*}$ \\
\hline $\mathrm{C} 4$ & $0.37666(7)$ & $0.49095(9)$ & $0.28582(15)$ & 0.03765 (14) \\
\hline H14 & $0.410(10)$ & $0.4425(4)$ & $0.3608(9)$ & $0.0464(5)^{*}$ \\
\hline C6 & $0.45508(6)$ & $0.62439(8)$ & 0.40909 (13) & $0.03502(12)$ \\
\hline H10 & $0.4772(4)$ & $0.692(10)$ & $0.3770(9)$ & $0.0523(5)^{*}$ \\
\hline H11 & $0.499(10)$ & $0.5723(4)$ & $0.4226(10)$ & $0.0523(5)^{*}$ \\
\hline $\mathrm{H} 12$ & $0.4374(4)$ & $0.6349(7)$ & $0.513(10)$ & $0.0522(5)^{*}$ \\
\hline $\mathrm{C} 5$ & $0.32202(8)$ & $0.45601(8)$ & $0.17956(18)$ & $0.04085(15)$ \\
\hline H13 & $0.3110(6)$ & $0.379(10)$ & $0.1731(12)$ & $0.0506(5)^{*}$ \\
\hline
\end{tabular}


Atomic displacement parameters $\left(\AA^{2}\right)$

\begin{tabular}{lllllll}
\hline & $U^{11}$ & $U^{22}$ & $U^{33}$ & $U^{12}$ & $U^{13}$ & $U^{23}$ \\
\hline $\mathrm{C} 1$ & $0.02111(12)$ & $0.02624(15)$ & $0.01251(14)$ & $0.00064(10)$ & $0.00457(9)$ & $0.00235(11)$ \\
$\mathrm{N} 2$ & $0.0193(4)$ & $0.0218(5)$ & $0.0124(5)$ & $-0.0053(4)$ & $0.0050(3)$ & $-0.0019(4)$ \\
$\mathrm{N} 3$ & $0.0189(4)$ & $0.0286(6)$ & $0.0135(5)$ & $-0.0043(4)$ & $0.0061(4)$ & $-0.0024(4)$ \\
$\mathrm{N} 4$ & $0.0276(5)$ & $0.0197(5)$ & $0.0135(5)$ & $-0.0037(4)$ & $0.0070(4)$ & $-0.0023(4)$ \\
$\mathrm{N} 5$ & $0.0334(5)$ & $0.0224(5)$ & $0.0140(5)$ & $-0.0096(4)$ & $0.0085(4)$ & $-0.0021(4)$ \\
$\mathrm{N} 6$ & $0.0196(4)$ & $0.0427(7)$ & $0.0132(5)$ & $-0.0091(4)$ & $0.0040(4)$ & $-0.0041(5)$ \\
$\mathrm{C} 7$ & $0.0177(5)$ & $0.0217(6)$ & $0.0128(6)$ & $-0.0026(4)$ & $0.0044(4)$ & $-0.0013(5)$ \\
$\mathrm{C} 8$ & $0.0193(5)$ & $0.0187(6)$ & $0.0136(6)$ & $-0.0030(4)$ & $0.0040(4)$ & $-0.0014(5)$ \\
$\mathrm{C} 9$ & $0.0228(5)$ & $0.0209(6)$ & $0.0198(6)$ & $-0.0025(4)$ & $0.0097(4)$ & $-0.0023(5)$ \\
$\mathrm{C} 1$ & $0.0272(6)$ & $0.0225(6)$ & $0.0309(7)$ & $0.0004(5)$ & $0.0100(5)$ & $0.0019(6)$ \\
$\mathrm{C} 2$ & $0.0296(6)$ & $0.0275(7)$ & $0.0267(7)$ & $-0.0071(5)$ & $0.0061(5)$ & $-0.0101(6)$ \\
$\mathrm{C} 3$ & $0.0390(7)$ & $0.0318(8)$ & $0.0411(9)$ & $-0.0097(6)$ & $0.0104(6)$ & $-0.0136(7)$ \\
$\mathrm{C} 4$ & $0.0437(8)$ & $0.0253(7)$ & $0.0470(10)$ & $0.0036(6)$ & $0.0164(7)$ & $0.0058(7)$ \\
$\mathrm{C} 6$ & $0.0337(7)$ & $0.0381(8)$ & $0.0322(8)$ & $0.0062(6)$ & $0.0015(6)$ & $0.0058(6)$ \\
$\mathrm{C} 5$ & $0.0487(8)$ & $0.0216(7)$ & $0.0554(11)$ & $-0.0071(6)$ & $0.0184(7)$ & $-0.0103(7)$ \\
& & & & & & \\
\hline
\end{tabular}

Geometric parameters $\left(\AA,{ }^{\circ}\right)$

\begin{tabular}{|c|c|c|c|}
\hline $\mathrm{N} 2-\mathrm{C} 8$ & $1.3306(13)$ & $\mathrm{C} 9-\mathrm{C} 1$ & $1.3938(16)$ \\
\hline $\mathrm{N} 2-\mathrm{C} 7$ & 1.3405 (14) & $\mathrm{C} 9-\mathrm{C} 2$ & $1.3986(15)$ \\
\hline $\mathrm{N} 3-\mathrm{C} 7$ & $1.3335(12)$ & $\mathrm{C} 1-\mathrm{C} 4$ & $1.4039(17)$ \\
\hline $\mathrm{N} 3-\mathrm{H} 1$ & $1.01(9)$ & $\mathrm{C} 1-\mathrm{C} 6$ & $1.4902(17)$ \\
\hline $\mathrm{N} 3-\mathrm{H} 2$ & $1.01(16)$ & $\mathrm{C} 2-\mathrm{C} 3$ & $1.3826(16)$ \\
\hline $\mathrm{N} 4-\mathrm{C} 8$ & $1.3516(14)$ & $\mathrm{C} 2-\mathrm{H} 8$ & $1.08(9)$ \\
\hline $\mathrm{N} 4-\mathrm{C} 9$ & $1.4179(14)$ & $\mathrm{C} 3-\mathrm{C} 5$ & $1.384(2)$ \\
\hline $\mathrm{N} 4-\mathrm{H} 4$ & $1.01(8)$ & $\mathrm{C} 3-\mathrm{H} 9$ & $1.08(11)$ \\
\hline $\mathrm{N} 5-\mathrm{C} 8$ & $1.3385(13)$ & $\mathrm{C} 4-\mathrm{C} 5$ & $1.3863(19)$ \\
\hline $\mathrm{N} 5-\mathrm{H} 3$ & $1.01(10)$ & $\mathrm{C} 4-\mathrm{H} 14$ & $1.08(9)$ \\
\hline $\mathrm{N} 5-\mathrm{H} 5$ & $1.01(9)$ & $\mathrm{C} 6-\mathrm{H} 11$ & $1.08(14)$ \\
\hline $\mathrm{N} 6-\mathrm{C} 7$ & $1.3334(13)$ & $\mathrm{C} 6-\mathrm{H} 10$ & $1.08(12)$ \\
\hline $\mathrm{N} 6-\mathrm{H} 7$ & $1.02(15)$ & $\mathrm{C} 6-\mathrm{H} 12$ & $1.08(9)$ \\
\hline N6- $\mathrm{H} 6$ & $1.02(9)$ & $\mathrm{C} 5-\mathrm{H} 13$ & $1.08(14)$ \\
\hline $\mathrm{C} 8-\mathrm{N} 2-\mathrm{C} 7$ & $122.46(8)$ & $\mathrm{C} 9-\mathrm{C} 1-\mathrm{C} 4$ & $116.95(10)$ \\
\hline $\mathrm{C} 7-\mathrm{N} 3-\mathrm{H} 1$ & $120(4)$ & $\mathrm{C} 9-\mathrm{C} 1-\mathrm{C} 6$ & $123.10(9)$ \\
\hline $\mathrm{C} 7-\mathrm{N} 3-\mathrm{H} 2$ & $120(8)$ & $\mathrm{C} 4-\mathrm{C} 1-\mathrm{C} 6$ & $119.91(10)$ \\
\hline $\mathrm{H} 1-\mathrm{N} 3-\mathrm{H} 2$ & $120(2)$ & $\mathrm{C} 9-\mathrm{C} 2-\mathrm{C} 3$ & $120.24(10)$ \\
\hline $\mathrm{C} 8-\mathrm{N} 4-\mathrm{C} 9$ & $125.79(8)$ & $\mathrm{C} 9-\mathrm{C} 2-\mathrm{H} 8$ & $119(3)$ \\
\hline $\mathrm{C} 8-\mathrm{N} 4-\mathrm{H} 4$ & $115(4)$ & $\mathrm{C} 3-\mathrm{C} 2-\mathrm{H} 8$ & $120(7)$ \\
\hline $\mathrm{C} 9-\mathrm{N} 4-\mathrm{H} 4$ & $118.7(6)$ & $\mathrm{C} 2-\mathrm{C} 3-\mathrm{C} 5$ & $119.24(10)$ \\
\hline $\mathrm{C} 8-\mathrm{N} 5-\mathrm{H} 3$ & $121(7)$ & $\mathrm{C} 2-\mathrm{C} 3-\mathrm{H} 9$ & $121(2)$ \\
\hline $\mathrm{C} 8-\mathrm{N} 5-\mathrm{H} 5$ & $119(1)$ & $\mathrm{C} 5-\mathrm{C} 3-\mathrm{H} 9$ & $120(4)$ \\
\hline $\mathrm{H} 3-\mathrm{N} 5-\mathrm{H} 5$ & $119(4)$ & $\mathrm{C} 1-\mathrm{C} 4-\mathrm{C} 5$ & $121.61(11)$ \\
\hline $\mathrm{C} 7-\mathrm{N} 6-\mathrm{H} 7$ & $120(9)$ & $\mathrm{C} 1-\mathrm{C} 4-\mathrm{H} 14$ & $117(2)$ \\
\hline $\mathrm{C} 7-\mathrm{N} 6-\mathrm{H} 6$ & $119(1)$ & $\mathrm{C} 5-\mathrm{C} 4-\mathrm{H} 14$ & $122(6)$ \\
\hline
\end{tabular}




\begin{tabular}{|c|c|c|c|}
\hline $\mathrm{H} 7-\mathrm{N} 6-\mathrm{H} 6$ & $120(4)$ & $\mathrm{C} 1-\mathrm{C} 6-\mathrm{H} 11$ & $111(7)$ \\
\hline $\mathrm{N} 2-\mathrm{C} 7-\mathrm{N} 6$ & $124.79(8)$ & $\mathrm{C} 1-\mathrm{C} 6-\mathrm{H} 10$ & $111(2)$ \\
\hline $\mathrm{N} 2-\mathrm{C} 7-\mathrm{N} 3$ & $117.54(8)$ & $\mathrm{C} 1-\mathrm{C} 6-\mathrm{H} 12$ & $111(3)$ \\
\hline $\mathrm{N} 6-\mathrm{C} 7-\mathrm{N} 3$ & $117.61(8)$ & $\mathrm{H} 11-\mathrm{C} 6-\mathrm{H} 10$ & $107(6)$ \\
\hline $\mathrm{N} 4-\mathrm{C} 8-\mathrm{N} 2$ & $118.60(8)$ & $\mathrm{H} 11-\mathrm{C} 6-\mathrm{H} 12$ & $108(4)$ \\
\hline $\mathrm{N} 4-\mathrm{C} 8-\mathrm{N} 5$ & $116.01(8)$ & $\mathrm{H} 10-\mathrm{C} 6-\mathrm{H} 12$ & $108(2)$ \\
\hline $\mathrm{N} 2-\mathrm{C} 8-\mathrm{N} 5$ & $125.27(8)$ & $\mathrm{C} 3-\mathrm{C} 5-\mathrm{C} 4$ & $120.43(11)$ \\
\hline $\mathrm{N} 4-\mathrm{C} 9-\mathrm{C} 1$ & $121.39(9)$ & $\mathrm{C} 3-\mathrm{C} 5-\mathrm{H} 13$ & $120(5)$ \\
\hline $\mathrm{N} 4-\mathrm{C} 9-\mathrm{C} 2$ & $116.92(9)$ & $\mathrm{C} 4-\mathrm{C} 5-\mathrm{H} 13$ & $119(3)$ \\
\hline $\mathrm{C} 1-\mathrm{C} 9-\mathrm{C} 2$ & $121.48(10)$ & & \\
\hline $\mathrm{N} 2-\mathrm{C} 8-\mathrm{N} 4-\mathrm{C} 9$ & $-16.30(15)$ & $\mathrm{C} 8-\mathrm{N} 4-\mathrm{C} 9-\mathrm{C} 2$ & $127.35(15)$ \\
\hline $\mathrm{N} 2-\mathrm{C} 8-\mathrm{N} 4-\mathrm{H} 4$ & $166(2)$ & $\mathrm{C} 9-\mathrm{C} 1-\mathrm{C} 4-\mathrm{C} 5$ & $1.41(17)$ \\
\hline $\mathrm{N} 2-\mathrm{C} 8-\mathrm{N} 5-\mathrm{H} 3$ & $-8(4)$ & $\mathrm{C} 9-\mathrm{C} 1-\mathrm{C} 4-\mathrm{H} 14$ & $180(9)$ \\
\hline $\mathrm{N} 2-\mathrm{C} 8-\mathrm{N} 5-\mathrm{H} 5$ & $-173(3)$ & $\mathrm{C} 9-\mathrm{C} 1-\mathrm{C} 6-\mathrm{H} 11$ & $-143(9)$ \\
\hline $\mathrm{N} 2-\mathrm{C} 7-\mathrm{N} 6-\mathrm{H} 7$ & $-5(4)$ & $\mathrm{C} 9-\mathrm{C} 1-\mathrm{C} 6-\mathrm{H} 10$ & $-24(1)$ \\
\hline $\mathrm{N} 2-\mathrm{C} 7-\mathrm{N} 6-\mathrm{H} 6$ & $-171(2)$ & $\mathrm{C} 9-\mathrm{C} 1-\mathrm{C} 6-\mathrm{H} 12$ & $96(5)$ \\
\hline $\mathrm{N} 2-\mathrm{C} 7-\mathrm{N} 3-\mathrm{H} 1$ & $175(2)$ & $\mathrm{C} 9-\mathrm{C} 2-\mathrm{C} 3-\mathrm{C} 5$ & $-0.72(17)$ \\
\hline $\mathrm{N} 2-\mathrm{C} 7-\mathrm{N} 3-\mathrm{H} 2$ & $0(5)$ & $\mathrm{C} 9-\mathrm{C} 2-\mathrm{C} 3-\mathrm{H} 9$ & $-179(10)$ \\
\hline $\mathrm{N} 3-\mathrm{C} 7-\mathrm{N} 2-\mathrm{C} 8$ & $156.67(15)$ & $\mathrm{C} 1-\mathrm{C} 9-\mathrm{C} 2-\mathrm{C} 3$ & $1.78(17)$ \\
\hline $\mathrm{N} 3-\mathrm{C} 7-\mathrm{N} 6-\mathrm{H} 7$ & $172(4)$ & $\mathrm{C} 1-\mathrm{C} 9-\mathrm{C} 2-\mathrm{H} 8$ & $-170(1)$ \\
\hline $\mathrm{N} 3-\mathrm{C} 7-\mathrm{N} 6-\mathrm{H} 6$ & $6(2)$ & $\mathrm{C} 1-\mathrm{C} 4-\mathrm{C} 5-\mathrm{C} 3$ & $-0.44(19)$ \\
\hline $\mathrm{H} 1-\mathrm{N} 3-\mathrm{C} 7-\mathrm{N} 6$ & $-2(2)$ & $\mathrm{C} 1-\mathrm{C} 4-\mathrm{C} 5-\mathrm{H} 13$ & $180(1)$ \\
\hline $\mathrm{H} 2-\mathrm{N} 3-\mathrm{C} 7-\mathrm{N} 6$ & $-178(5)$ & $\mathrm{C} 2-\mathrm{C} 9-\mathrm{C} 1-\mathrm{C} 4$ & $-2.07(16)$ \\
\hline $\mathrm{N} 4-\mathrm{C} 8-\mathrm{N} 2-\mathrm{C} 7$ & $157.09(14)$ & $\mathrm{C} 2-\mathrm{C} 9-\mathrm{C} 1-\mathrm{C} 6$ & $175.84(17)$ \\
\hline $\mathrm{N} 4-\mathrm{C} 8-\mathrm{N} 5-\mathrm{H} 3$ & $168(4)$ & $\mathrm{C} 2-\mathrm{C} 3-\mathrm{C} 5-\mathrm{C} 4$ & $0.07(19)$ \\
\hline $\mathrm{N} 4-\mathrm{C} 8-\mathrm{N} 5-\mathrm{H} 5$ & $3(2)$ & $\mathrm{C} 2-\mathrm{C} 3-\mathrm{C} 5-\mathrm{H} 13$ & $180(1)$ \\
\hline $\mathrm{N} 4-\mathrm{C} 9-\mathrm{C} 1-\mathrm{C} 4$ & $-176.71(15)$ & $\mathrm{H} 8-\mathrm{C} 2-\mathrm{C} 3-\mathrm{C} 5$ & $171(2)$ \\
\hline $\mathrm{N} 4-\mathrm{C} 9-\mathrm{C} 1-\mathrm{C} 6$ & $1.20(15)$ & $\mathrm{H} 8-\mathrm{C} 2-\mathrm{C} 3-\mathrm{H} 9$ & $-7(11)$ \\
\hline $\mathrm{N} 4-\mathrm{C} 9-\mathrm{C} 2-\mathrm{C} 3$ & $176.65(15)$ & $\mathrm{C} 3-\mathrm{C} 5-\mathrm{C} 4-\mathrm{H} 14$ & $-179(10)$ \\
\hline $\mathrm{N} 4-\mathrm{C} 9-\mathrm{C} 2-\mathrm{H} 8$ & $4(2)$ & $\mathrm{H} 9-\mathrm{C} 3-\mathrm{C} 5-\mathrm{C} 4$ & $179(13)$ \\
\hline $\mathrm{H} 4-\mathrm{N} 4-\mathrm{C} 8-\mathrm{N} 5$ & $-10(2)$ & $\mathrm{H} 9-\mathrm{C} 3-\mathrm{C} 5-\mathrm{H} 13$ & $-2(13)$ \\
\hline $\mathrm{H} 4-\mathrm{N} 4-\mathrm{C} 9-\mathrm{C} 1$ & $120(2)$ & $\mathrm{C} 4-\mathrm{C} 1-\mathrm{C} 6-\mathrm{H} 11$ & $35(9)$ \\
\hline $\mathrm{H} 4-\mathrm{N} 4-\mathrm{C} 9-\mathrm{C} 2$ & $-55(2)$ & $\mathrm{C} 4-\mathrm{C} 1-\mathrm{C} 6-\mathrm{H} 10$ & $154(1)$ \\
\hline $\mathrm{N} 5-\mathrm{C} 8-\mathrm{N} 4-\mathrm{C} 9$ & $167.49(15)$ & $\mathrm{C} 4-\mathrm{C} 1-\mathrm{C} 6-\mathrm{H} 12$ & $-86(5)$ \\
\hline $\mathrm{N} 5-\mathrm{C} 8-\mathrm{N} 2-\mathrm{C} 7$ & $-27.08(15)$ & $\mathrm{H} 14-\mathrm{C} 4-\mathrm{C} 1-\mathrm{C} 6$ & $2(13)$ \\
\hline $\mathrm{N} 6-\mathrm{C} 7-\mathrm{N} 2-\mathrm{C} 8$ & $-26.32(16)$ & $\mathrm{H} 14-\mathrm{C} 4-\mathrm{C} 5-\mathrm{H} 13$ & $2(13)$ \\
\hline $\mathrm{C} 8-\mathrm{N} 4-\mathrm{C} 9-\mathrm{C} 1$ & $-57.78(16)$ & $\mathrm{C} 6-\mathrm{C} 1-\mathrm{C} 4-\mathrm{C} 5$ & $-176.57(18)$ \\
\hline
\end{tabular}

Hydrogen-bond geometry $\left(A,{ }^{\circ}\right)$

\begin{tabular}{lllll}
\hline$D-\mathrm{H} \cdots A$ & $D-\mathrm{H}$ & $\mathrm{H} \cdots A$ & $D \cdots A$ & $D-\mathrm{H} \cdots A$ \\
\hline $\mathrm{N} 4-\mathrm{H} 4 \cdots \mathrm{Cl}$ & $1.01(8)$ & $2.17(7)$ & $3.1584(9)$ & $163(1)$ \\
$\mathrm{N} 5-\mathrm{H} 5 \cdots \mathrm{Cl}$ & $1.01(9)$ & $2.37(9)$ & $3.2880(9)$ & $150(6)$ \\
$\mathrm{N} 6-\mathrm{H} 7 \cdots \mathrm{N} 5$ & $1.02(15)$ & $2.52(6)$ & $2.9156(13)$ & $103(5)$ \\
$\mathrm{C} 6-\mathrm{H} 10 \cdots \mathrm{C} 8$ & $1.08(12)$ & $2.65(9)$ & $3.1420(15)$ & $108(5)$ \\
$\mathrm{N} 3-\mathrm{H} 1 \cdots \mathrm{Cl}$ & $1.01(9)$ & $2.44(6)$ & $3.3431(9)$ & $148(4)$ \\
$\mathrm{N} 6-\mathrm{H} 6 \cdots \mathrm{Cl}^{\mathrm{i}}$ & $1.02(9)$ & $2.28(9)$ & $3.2398(9)$ & $157(1)$
\end{tabular}


supporting information

\begin{tabular}{lllll}
$\mathrm{N} 5-\mathrm{H} 3 \cdots \mathrm{Cl}^{\mathrm{ii}}$ & $1.01(10)$ & $2.32(13)$ & $3.2454(9)$ & $150(3)$ \\
$\mathrm{N} 6-\mathrm{H} 7 \cdots \mathrm{Cl}^{\mathrm{ii}}$ & $1.02(15)$ & $2.34(18)$ & $3.2284(9)$ & $146(11)$ \\
$\mathrm{N} 3-\mathrm{H} 2 \cdots \mathrm{N} 2^{\mathrm{iv}}$ & $1.01(16)$ & $1.96(15)$ & $2.9754(12)$ & $174(1)$ \\
\hline
\end{tabular}

Symmetry codes: (i) $x, y, z+1$; (ii) $x,-y+2, z+1 / 2$; (iii) $-x+1, y,-z+1 / 2$; (iv) $-x+1 / 2,-y+3 / 2,-z+1$. 